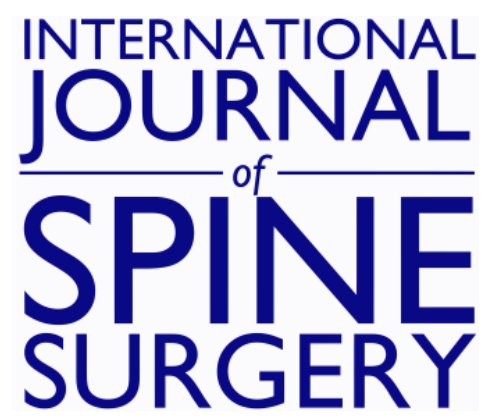

\title{
Indications for Lumbar Total Disc Replacement: Selecting the Right Patient with the Right Indication for the Right Total Disc
}

Karin Büttner-Janz, Dr.med., Prof., Richard D. Guyer and Donna D. Ohnmeiss, Dr.Med.

Int J Spine Surg 2014, 8 ()

doi: https://doi.org/10.14444/1012

http://ijssurgery.com/content/8/12

This information is current as of April 26, 2023.

Email Alerts Receive free email-alerts when new articles cite this article. Sign up at:

http://ijssurgery.com/alerts 


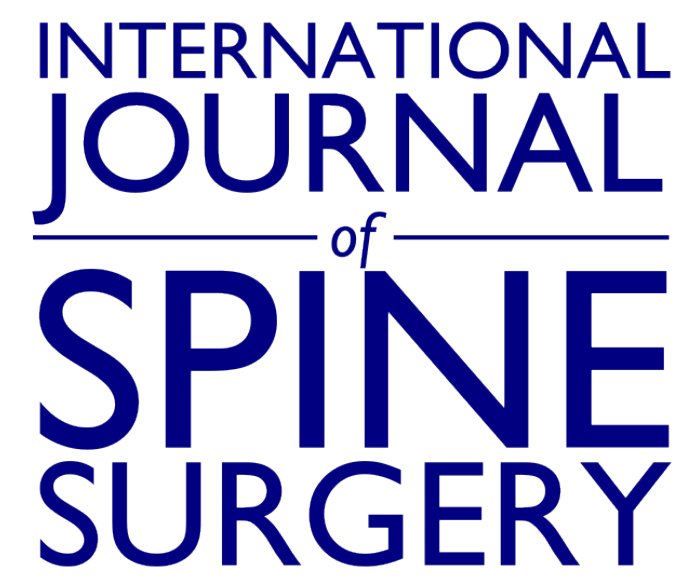

This article generously published free of charge by the International Society for the Advancement of Spine Surgery.

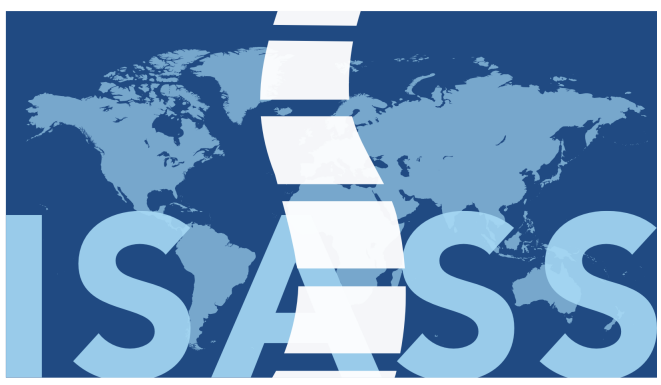

INTERNATIONAL SOCIETY for the ADVANCEMENT of SPINE SURGERY 


\section{Indications for Lumbar Total Disc Replacement: Selecting the Right Patient with the Right Indication for the Right Total Disc}

Karin Büttner-Janz, Dr.med., Prof., ${ }^{1}$ Richard D. Guyer, MD, ${ }^{2}$ Donna D. Ohnmeiss, Dr.Med. ${ }^{3}$

${ }^{1}$ Büttner-Janz Spinefoundation, Berlin, Germany; ${ }^{2}$ Texas Back Institute, Plano, Texas; ${ }^{3}$ Texas Back Institute Research Foundation, Plano, Texas

\section{Abstract}

\section{Summary of Background Data}

As with any surgery, care should be taken to determine patient selection criteria for lumbar TDR based on safety and optimizing outcome. These goals may initially be addressed by analyzing biomechanical implant function and early clinical experience, ongoing evaluation is needed to refine indications.

\section{Objective}

The purpose of this work was to synthesize information published on general indications for lumbar TDR. A secondary objective was to determine if indications vary for different TDR designs.

\section{Methods}

A comprehensive literature search was conducted to identify lumbar TDR articles.

Articles were reviewed and patient selection criteria and indications were synthesized.

\section{Results}

With respect to safety, there was good agreement in the literature to exclude patients with osteopenia/osteoporosis or fracture. Risk of injury to vascular structures due to the anterior approach was often addressed by excluding patients with previous abdominal surgery in the area of disc pathology or increased age. The literature was very consistent on the primary indication for TDR being painful disc degeneration unresponsive to at least 6 months of nonoperative care. Literature investigating the impact of previous spine surgery was mixed; however, prior surgery was not necessarily a contra-indication, provided the patient otherwise met selection criteria. The literature was mixed on setting a minimum preoperative disc height as a selection criterion. There were no publications investigating whether some patients are better/worse candidates for specific TDR designs. Based on the literature a proposal for patient selection criteria is offered. 


\section{Conclusions}

Several TDR indications and contra-indications are widely accepted. No literature addresses particular TDR design being preferable for some patients. As with any spine surgery, ongoing evaluation of TDR outcomes will likely lead to more detailed general and device design specific indications.

keywords: total disc replacement, lumbar spine, indications, comprehensive literature overview

Volume 8 Article 12 doi: 10.14444/1012

\section{Introduction}

Some surgeons believe in strict adherence to a relatively short list of indications for total disc replacement (TDR). Singh et al. ${ }^{1}$ proposed that if TDR use follows the pattern of pedicle screws and cylindrical cages, rapid growth will be followed by expanded indications, resulting in inconsistent clinical outcomes and increased complications, leading to curtailed use. If TDR is used in 'properly indicated patients', this rise and fall in use may be avoided. The appropriate indication for surgery is critical for success. ${ }^{2}$ The first purpose of this review is to evaluate information regarding general indications for $T D R$. The second purpose is to develop an overview for determining specific indications for different TDRs.

\section{Indications for Lumbar Fusion}

Lumbar fusion is used to treat pain attributed to abnormal motion or mechanical insufficiency produced by degenerative change. ${ }^{3}$ Often compressed nerves are released simultaneously to reduce back and leg pain. In the last 40 years, indications for fusion have remained largely constant. Described indications include: degenerative disc disease (DDD), isthmic spondylolisthesis, unstable spinal stenosis, degenerative spondylolisthesis, degenerative scoliosis, segmental instability, disc-related back pain, failed previous surgery, and post-facetectomy syndrome. ${ }^{3,4}$ Bambakidis et.al. ${ }^{4}$ define radiographic instability of a motion segment as translational motion of $>3 \mathrm{~mm}$ in levels above L5-S1 or $5 \mathrm{~mm}$ at L5-S1, or motion segment angulation of $>10^{\circ}$ on lateral flexion/ extension radiographs.

\section{General Indications for Lumbar TDR}

Some fusion indications have been found to be appropriate for lumbar TDR, as demonstrated in randomized Food and Drug Administration Investigational Device Exemption (FDA IDE) studies with up to five-year follow-up. ${ }^{5,6}$ Wong et al. ${ }^{7}$ proposed that the ideal TDR patient is likely earlier in the Kirkaldy-Willis degenerative cascade than a fusion patient. The primary indication for lumbar TDR is symptomatic DDD. ${ }^{7,8,9,10,11,12,13,14,15,16,17,18,19,20,21,22,23,24,25,26,27,28,29 ~ I n ~ d e f i n i n g ~ g e n e r a l ~ i n d i c a t i o n s, ~}$ data needed includes patient history, pain and disability, clinical and image findings, diagnostic procedures, and psychosocial factors. TDR indications/contraindications literature is summarized below. 


\section{Patient data and medical history}

Many contraindications are related to personal and medical characteristics (Table 1). Age ranges in different studies included: 18-60 years; $9,16,18,21,26,28,29,30,31,32,33,34,3518-70$ years, ${ }^{36,37}$ 20-55 years, ${ }^{38}$ 20-60 years, ${ }^{19}$ and, 30-55 years. ${ }^{13}$ One study investigated a population over 60 years old and recommended TDR for patients with adequate bone quality and without circumferential spinal stenosis. ${ }^{39}$

TDRs were implanted after failed nonoperative therapy for a minimum of 6 months, ${ }^{8,9,13,16,18,19,25,26,28,29,32,33,34,35,36,37,40,41,42}$ although nonoperative therapy duration varied from 338 to 9 months. ${ }^{30}$

Several studies included patients with prior surgery, such as microdiscectomy or percutaneous nucleotomy. ${ }^{12,16,17,24,26,40,42,43}$ Others allowed patients with failed disc excision, ${ }^{11}$ failed spine surgery, ${ }^{26}$ prior fusion with adjacent segment disease (ASD) ${ }^{12,41,44,45}$ and below a previous long fusion for scoliosis. ${ }^{46}$ Bertagnoli et al. ${ }^{30,44}$ found no differences in outcomes for patients with prior posterior discectomy or laminectomy vs. those with no previous surgery for both single- and multi-level TDR. Leahy et al. ${ }^{14}$ found no statistically significant differences in outcomes for patients with no previous lumbar surgery vs. those with a previous discectomy. Geisler et al. ${ }^{47}$ studied patients from the Charite IDE trial with and without prior back surgery. There were no significant differences in Oswestry Disability Index (ODI) and visual analog scales (VAS) pain scores. At 2-year follow-up, both groups had similar levels of satisfaction and return-to-work. Tropiano et al. ${ }^{26}$ found satisfactory results in $90 \%$ of patients with previous surgery. Zeegers et al. ${ }^{43}$ found that previous surgery was not related to outcome at 2-year follow-up, in contrast to 1 -year results. Siepe et al. ${ }^{24}$ found no significant differences between DDD and DDD post-discectomy groups. Pre-existing leg pain did not deteriorate after disc replacement. Others suggest a negative impact of previous spine surgery on outcomes. Gornet et al. ${ }^{36}$ described exclusion criteria as prior posterior lumbar surgery with significant morbidity, but discectomy, laminotomy/laminectomy, and intradiscal procedures were not excluded. Blondel et al. ${ }^{48}$ found that patients with previous surgery at the TDR level had the poorest outcomes. ODI scores were significantly higher for patients with postdiscectomy syndrome. Radicular pain VAS scores were significantly higher for patients with recurrent disc herniation. Tropiano et al. ${ }^{25,26}$ reported patients with failed back surgery experienced notable radicular pain after ProDisc implantation, possibly due to epidural fibrosis resulting in nerve root traction after intervertebral distraction.

\section{Pain and disability}

TDR indications are generally back and/or leg pain with no nerve root compression ${ }^{9,28,30,49}$ or back pain with/without leg pain. ${ }^{13,16,29,34,35,36,38,40,42}$ These symptoms can be quantified using patient self-assessments. For potential TDR patients, indications have been described as preoperative VAS back pain scores of at least $40^{9,18,34,35,37}$ or $50^{38}$ of 100 . Preoperative ODI score $>30 \% 0^{9,18,19,33,35,36,38}$ or $40 \% 0^{29,32,37}$ have been required. 


\section{Clinical findings}

There is no specific literature about clinical examination prior to TDR. In case of CT scan or MRI findings of central canal and/or the lateral recess stenosis, clinical evaluation should focus on nerve compression.

\section{Imaging}

X-ray, CT, or MRI findings are used to further define indications for TDR. X-rays are used primarily to assess bony anatomy and alignment, and used to exclude diagnoses such as scoliosis, spondylolisthesis, and fractures. ${ }^{50} \mathrm{CTs}$ are also used to exclude other diagnoses. CT may be used to assess the spinal canal, vertebral bony anatomy and posterior joints, and may be more effective than X-rays for identifying osteophytes or endplate sclerosis. MRI can be used to evaluate the spinal canal, space for neural structures, bony alignment and facet joints, and provides direct assessment of neural and disc structures. ${ }^{50}$

The role of preoperative disc height has been investigated. Suggested indications for TDR included an intervertebral disc height of $>4 \mathrm{~mm}$, with or without scarring, and thickening of annulus fibrosis with osteophytes indicating osteoarthritis. ${ }^{16,31}$ However, Bertagnoli et al. ${ }^{30}$ showed that preoperative disc height did not effect outcomes, while Siepe et al. ${ }^{22}$ found that patients with more advanced DDD and reduced disc height had superior satisfaction rates. They found TDR was a viable treatment for advanced DDD, but reduced ROM should be expected.

Some variations in indications include mono-segmental DDD with or without Modic changes, ${ }^{24}$ DDD and contained disc herniation, ${ }^{24}$ segmental instability due to DDD, ${ }^{12,45}$ isolated disc resorption, ${ }^{12}$ abnormal discs related to genetic inability to form normal collagen, ${ }^{12}$ stenosis where fusion is indicated, ${ }^{12,45}$ low-grade spondylolisthesis, ${ }^{12,45}$ and degenerative rotational scoliolis. ${ }^{44}$ Jehan et al. ${ }^{46}$ allowed previous long fusion for scoliosis. Siepe et al. ${ }^{24}$ compared clinical outcomes in TDR patients with DDD, DDD+disc herniation, DDD post-discectomy, and DDD+Modic changes. All groups improved, with the best results achieved for DDD+disc herniation. Modic changes did not significantly influence outcome.

Radiographic measures including sacral tilt, pelvic tilt, pelvic incidence, and global lordosis are used to characterize sagittal balance. While some studies found that DDD patients generally do not have abnormal sagittal balance, ${ }^{51,52}$ others reported improved balance post-TDR. ${ }^{53,54}$

\section{Invasive diagnostic procedures}

Provocative discography has been described as the single most important diagnostic tool for DDD. ${ }^{50}$ It is recommended for patients who failed nonoperative treatment and whose X-rays and MRI show now other obvious pathologies. ${ }^{56}$ Berg et al. ${ }^{58}$ found that the surgical decision changed in $71 \%$ of patients based on information gained from discography. 
Facet joint injections are important to determine if pain is facet mediated, in which case TDR may be contra-indicated. Compromised outcomes were associated with more severe, multilevel degenerative disease including facet arthritis. ${ }^{32}$

\section{Bone quality}

Vertebral body fracture can occur during TDR placement or postoperatively. This can be a serious complication. Another risk is device subsidence into the vertebral body, resulting in pain and/or compromised biomechanical TDR function. In a cadaveric study, Lee $^{59}$ investigated bone mineral density (BMD) assessed by CT. He suggested BMD not be $<-1.5$ standard deviations below the mean value for young adults. For values of -2.0 to -1.5 , he advised caution, and TDR be avoided in patients with T-scores $<-2$. Some studies used osteoporosis as an exclusion criteria, ${ }^{29}$ other used osteopenia. ${ }^{9,21}$ Currently, it seems general consensus is to exclude patients with DEXA T-scores $<-1.0$, the World Health Organization definition of osteopenia. ${ }^{60}$

\section{Psychosocial and psychological factors}

Psychosocial factors have more impact on back pain disability than biomedical or biomechanical factors. ${ }^{61}$ Most clearly linked to back pain are depression, anxiety, distress, self-perceived poor health, and sexual and/or physical abuse. ${ }^{61}$ Depression, anxiety, psychosis, bipolar disorder, and narcotic abuse, can significantly affect surgical outcomes. ${ }^{62}$ Patients with both medical and psychosocial risk factors had the poorest outcomes. ${ }^{62}$ TDR inclusion criteria require that patients are mentally, emotionally, and physically able to understand the procedure, grant informed consent, and comply with postoperative care instructions.

\section{Levels operated}

Siepe et al. ${ }^{23}$ found that ProDisc at L4-L5 resulted in better outcomes and higher patient satisfaction than use at L5-S1; however, L5-S1 patients had lower complication and reoperation rates. Some studies evaluated single-level TDR only at L4-L5 or L5-S1, 9,18,21,22,28,33,35,36 others included two-level TDR from L3 to $\mathrm{S} 1,8,10,11,13,15,17,29,31,32,37,41$ and some included three-level ${ }^{26}$ and four-level ${ }^{12,44} \mathrm{TDR}$. Tropiano et al. ${ }^{25,26}$ found TDR could be used successfully at 2 or 3 contiguous levels. Zigler et al. ${ }^{64}$ found no differences in 1-vs. 2-level outcomes, with both groups improving significantly. Siepe et al. ${ }^{23}$ reported better outcomes for single-level than for 2-level procedures, associated with greater complication and reoperation rates. Siepe et al. ${ }^{24}$ found bisegmental TDR results deteriorated at 12 and 24 months compared with the monosegmental outcomes. Patient satisfaction rates were $85.7 \%$ for mono- and $64.3 \%$ for bi-segmental TDR. Chin ${ }^{31}$ found more favorable results in patients with isolated disc disease compared with multi-level disease. 


\section{TDR contraindications}

In studies reviewing large series of fusion cases to determine how many would have been TDR candidates, the figure was $<10 \% .{ }^{7,31}$ Numerous contraindications to TDR are cited in the literature (Table 1). Chin et al. ${ }^{31}$ and Huang et al. ${ }^{65}$ considered contraindications to fall under two broad categories: 1) Painful conditions not caused by the disc, and 2) Conditions that may compromise long-term device functionality.

\section{Table 1. Contraindications to TDR Cited in Clinical Studies}

\begin{tabular}{|c|c|}
\hline Anatomical / inherent / degenerative / mechanical & Subsidence / dislocation risk \\
\hline Pars defects ${ }^{37}$ & Osteoporosis $7,9,19,21,25,26,33,34,36,43,8,29,30,37,38,44,49,65,79,80$ \\
\hline $\begin{array}{l}\text { Fracture at } \mathrm{L} 4, \mathrm{~L} 5 \text { or } \mathrm{S} 1^{9} \text { or compromised vertebral } \\
\text { body } 7,16,24,29,35,38,79,81\end{array}$ & Endocrine or metabolic disorder known to affect osteogenesis ${ }^{36}$ \\
\hline Disc height $<3 \mathrm{~mm}^{10},<4 \mathrm{~mm}^{7}$ & Metabolic bone disease $7,9,19,21,24,29,37,43,49,81$ \\
\hline End stage disc resorption and collapse ${ }^{19}$ & Osteopenia ${ }^{7,9,12,16,19,21,26,31,37,49,82}$ \\
\hline Facet ankylosis $^{7}$ & Osteopathy $^{7}$ \\
\hline $\begin{array}{l}\text { Facet joint arthrosis/ } \\
\text { degeneration } 7,8,9,10,11,12,14,15,16,17,19,21,24,25,26,29,30,31,33,34,35,37,38,41,44,49,65 \text {, } \\
78,79,80,81,82,83\end{array}$ & Paget disease ${ }^{7,21}$ \\
\hline Retrolisthesis $^{7}$ & Chronic steroid use $9,19,21,29,37,49,83$ \\
\hline \multicolumn{2}{|l|}{ Posterior element insufficiency $7,21,24,26,36,43,65$} \\
\hline $\begin{array}{l}\text { Postsurgical deficiency of posterior elements }{ }^{25,31} \text { or prior posterior } \\
\text { lumbar surgery with significant morbidity }{ }^{36}\end{array}$ & Pathology not, or possibly not, treatable by TDR \\
\hline $\begin{array}{l}\text { Scoliosis } 7,9,12,13,16,21,24,31,33,34,35,36,37,40,49,65,81,84 \text { or major } \\
\text { deformity } 15,19,25,26,29,37,38,41,4482\end{array}$ & Nerve root compression ${ }^{7,16,35}$ \\
\hline Irregular vertebral body endplate shape $e^{7,24,29,81}$ & Positive straight leg raise ${ }^{9}$ \\
\hline Spondylosis ${ }^{7,9,16,21,24,30,31,35,37,43,49,65,81,82}$ & Radicular pain symptomology $7,15,19,29,37,43,81,82$ \\
\hline $\begin{array}{l}\text { Spondylolisthesis } 7,9,11,13,15,16,19,24,29,30,31,33,34,35,36,37,38,41,43,44,49, \\
65,78,80,81,82,83\end{array}$ & Straight leg raise producing pain below knee $\mathrm{e}^{16,35,37}$ \\
\hline Isthmic spondylolysis / olisthesis ${ }^{19,21,38}$ & $\begin{array}{l}\text { Noncontained herniated nucleus } \\
\text { pulposus } 7,9,12,16,1925,31,33,34,49,65,82\end{array}$ \\
\hline Lumbosacral joint anomalies $^{81}$ & Scarring from previous surgery ${ }^{43}$ \\
\hline Instability ${ }^{14,21,24,37,40,81}$ & Arachnoiditis $7,9,12,19,49$ \\
\hline Prior decompressive laminectomy ${ }^{12}$ & Stenosis $7,9,12,1319,21,24,25,29,30,31,33,34,36,37,38,41,43,44,49,65,78,81,82$ \\
\hline Previous fusion $7,9,11,15,16,19,21,29,30,33,34,36,37,38,44,49,79$ & 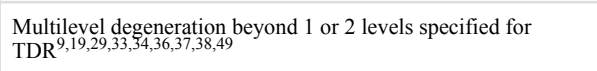 \\
\hline \multirow[t]{2}{*}{ Pseudoarthrosis $7,12,31,65$} & $\begin{array}{l}\text { Previous spinal surgery at affected level - except for discectomy, } \\
\text { laminotomy/ectomy, without accompanying facetotomy, or } \\
\text { intradiscal procedures at the level to be treated }\end{array}$ \\
\hline & Fibromyalgia $^{7}$ \\
\hline Possibly reaction on implant material & Cervical myelopathy $^{21}$ \\
\hline History of hypersensitivity to protein pharmaceuticals or collagen ${ }^{36}$ & \\
\hline
\end{tabular}




\begin{tabular}{|c|c|}
\hline History of implant rejection ${ }^{19}$ & General \\
\hline Metal allergy $7,9,19,24,29,30,34,36,37,44,49,79,81$ & Infection ${ }^{7,8,9,19,24,26,29,30,34,36,37,38,41,43,44,49,81}$ \\
\hline \multirow[t]{2}{*}{ History of anaphylaxis ${ }^{36}$} & Active hepatitis ${ }^{21}$ \\
\hline & Active malignancy ${ }^{19,21,29,34,36,37}$ \\
\hline Anterior approach related & 3 or more Waddell signs ${ }^{13}$ \\
\hline Obesity - definition varied with study $7-9,13,15,16,19,21,29,30,34,35,37,44,49$ & Autoimmune disorder $7,9,19,21,29,34,36,37,49,83$ \\
\hline Vascular anatomy that is aberrant ${ }^{7}$ & Pregnancy ${ }^{7,19} ?^{9,26,29,30,34,38,41,44,49,79}$ \\
\hline Vascular calcification $^{7}$ & Psychosocial disorder ${ }^{7,36} ?^{8,9,12,13,19,37,38,49,80}$ \\
\hline Previous abdominal surgery $7,26,37$ & Osteomyelitis ${ }^{7}$ \\
\hline Abdominal wall hernia ${ }^{12}$ & Spondylodiscitis $^{7}$ \\
\hline Previous iliofemoral phlebitis ${ }^{12}$ & $\begin{array}{l}\text { Chronic disease of a major organ - cardiac failure, hepatitis, } \\
\text { diabetes }^{7,26}\end{array}$ \\
\hline Abdominal pain profile ${ }^{19}$ & Neuromuscular disease ${ }^{30,44}$ \\
\hline Previous vascular surgery ${ }^{7}$ & Ankylosing spondylitis 7 \\
\hline Prior retroperitoneal radiation ${ }^{7,12,19}$ & Spinal tumor ${ }^{7,9,16,19,24,35,37,38,41,49,81}$ \\
\hline \multicolumn{2}{|l|}{ Prior surgery at the involved level $\mathrm{l}^{7,19,36,37,41,81}$} \\
\hline & Other \\
\hline & $\begin{array}{l}\text { Previous exposure to any or all bone morphogenetic proteins } \\
\text { (human or animal) }^{36}\end{array}$ \\
\hline
\end{tabular}

\section{Discussion}

There are several widely described general TDR indications including painful DDD unresponsive to $>6$ months of nonoperative care, no significant facet joint degeneration, no osteopenia/osteoporosis, and lack of conditions that may compromise outcome and/or interfere with proper TDR functioning such as severe instability. They are mainly base on FDA-study-related parameters and surgeons' experiences. To date, there is nothing published about potentially different indications for different TDR types with regard to design or materials.

\section{TDR Design and Material}

Lemaire et al. ${ }^{2}$ proposed that "disc prosthesis is indicated particularly in situations where restoration of a center of rotation and redefinition of segmental kinematics are required." But TDR designs simulate different disc functions. Inherent in current designs are disc height restoration, intervertebral angle, and varying degrees of motion and stability.

TDR designs include functional two- and three-component ball and socket variations with gliding surfaces and 1-piece designs consisting of multiple components bonded together or one compact component (Table 2). These designs inherently have different biomechanical characteristics, leading to advantages and disadvantages. Spherical ball and socket designs provide axial rotational without limitation, but with risk of damaging 
surrounding anatomy, namely facet joints. This design does not provide load sharing in axial compression. Nevertheless spherical ball and socket discs with polyethylene have minimal elastic features with potential positive influence on axial load distribution at the vertebral endplates. Spherical ball and socket discs are generally metal-on-metal, metalon-polyethylene, or PEEK-on-PEEK. Patients with metal-on-metal devices may have increased metallic ion levels from the implant, ${ }^{66,67,68}$ a phenomenon much more documented in hip implants. ${ }^{71,72,73}$ One TDR study found some of the serum ion levels to be greater than reported for hip replacements; ${ }^{66}$ while other studies found the levels to be similar for hip replacement ${ }^{67}$ and below levels determined high enough to merit monitoring of hip replacement patients68 as described by the Medicines and Healthcare Products Regulatory Agency ${ }^{69}$ or in more recent literature. ${ }^{70}$ Some metal-on-polyethylene designs may become impinged on one area of the core ${ }^{74}$ or on an area of the metal plates. ${ }^{75,76}$ Deformation and failure of polyethylene cores have occurred, often when devices were inaccurately placed or when inappropriate prosthetic components were used. 
Table 2. TDRs: Design and Materials.

\begin{tabular}{|c|c|c|}
\hline Name of TDR & Design & Material \\
\hline \multicolumn{3}{|c|}{ Functional three-component } \\
\hline $\begin{array}{l}\text { Charité Artificial } \\
\text { Disc (DePuy Spine) }\end{array}$ & 3 component ball and socket, 2 equal articulating surfaces & $\mathrm{CoCr}-\mathrm{UHMWPE}-\mathrm{CoCr}$ \\
\hline $\begin{array}{l}\text { InMotion (DePuy } \\
\text { Spine) }\end{array}$ & $\begin{array}{l}3 \text { component ball and socket, } 2 \text { equal articulating surfaces (further } \\
\text { development of Charité Artificial Disc) }\end{array}$ & $\mathrm{CoCr}-\mathrm{UHMWPE}-\mathrm{CoCr}$ \\
\hline $\begin{array}{l}\text { Kineflex-L (Spinal } \\
\text { Motion, Inc.) }\end{array}$ & 3 component ball and socket, 2 equal articulating surfaces & $\mathrm{CoCr}-\mathrm{CoCr}-\mathrm{CrCo}$ \\
\hline $\begin{array}{l}\text { Activ L (Aesculap / } \\
\text { BBraun) }\end{array}$ & 3 component ball and socket, 2 equal articulating surfaces & $\mathrm{CoCr}-\mathrm{UHMWPE}-\mathrm{CoCr}$ \\
\hline Dynardi (Zimmer) $^{\mathrm{NA}}$ & 3 component ball and socket, 2 equal articulating surfaces & $\mathrm{CoCr}-$ Sulene PE - CoCr \\
\hline $\begin{array}{l}\text { Mobidisc (LDR } \\
\text { Spine) }\end{array}$ & $\begin{array}{l}3 \text { component with } 2 \text { articulating surfaces: } 1 \text { ball and socket superior surface } \\
\text { and } 1 \text { flat inferior surface }\end{array}$ & $\mathrm{CoCr}-\mathrm{UHMWPE}-\mathrm{CoCr}$ \\
\hline $\begin{array}{l}\text { Orbit (Globus } \\
\text { Medical) }\end{array}$ & $\begin{array}{l}3 \text { component with } 2 \text { articulating surfaces: } 1 \text { ball and socket superior surface } \\
\text { and } 1 \text { cylindrical inferior surface (for extension/flexion) }\end{array}$ & PEEK - PEEK - PEEK \\
\hline \multicolumn{3}{|c|}{ Functional two-component } \\
\hline $\begin{array}{l}\text { ProDisc-L (DePuy } \\
\text { Synthes) }\end{array}$ & $\begin{array}{l}3 \text { component ball and socket, } 1 \text { articulating surface, core affixed to caudal } \\
\text { plate }\end{array}$ & $\mathrm{CoCr}$ - UHMWPE-CoCr \\
\hline $\begin{array}{l}\text { Maverick } \\
\text { (Medtronic) }^{I}\end{array}$ & 2 component ball and socket, 1 articulating surface & $\mathrm{CoCr}-\mathrm{CoCr}$ \\
\hline Flexicore (Stryker) ${ }^{\mathrm{I}}$ & $\begin{array}{l}2 \text { component ball and socket, } 1 \text { articulating surface, internal stiff stop of } \\
\text { axial rotation }\end{array}$ & $\mathrm{CoCr}-\mathrm{CoCr}$ \\
\hline$\underset{I}{X L}$ TDR (NuVasive) & 2 component ball and socket, 1 articulating surface & $\mathrm{CoCr}-\mathrm{CoCr}$ \\
\hline \multicolumn{3}{|c|}{ Functional one-component } \\
\hline Freedom (AxioMed) ${ }^{\mathrm{I}}$ & 1-piece bonded viscoelastic, no articulating surface & $\mathrm{Ti}-\mathrm{SPCU}-\mathrm{Ti}$ \\
\hline $\begin{array}{l}\text { M6-L (Spinal } \\
\text { Kinetics, Inc. })^{\text {NA }}\end{array}$ & 1-piece viscoelastic, with movable core - not bonded to plates & $\begin{array}{l}\mathrm{Ti} \text { - PCU core - Ti, UHMWPE fiber } \\
\text { annulus, PCU sheath }\end{array}$ \\
\hline Cadisc-L (Ranier) $^{\mathrm{NA}}$ & 1-piece bonded viscoelastic, no articulating surface & PCU with graduated modulus \\
\hline $\begin{array}{l}\text { LP-ESP (FH } \\
\text { Orthopedics) }\end{array}$ & 1-piece viscoelastic, no articulating surface & $\begin{array}{l}\text { Ti plates, silicone core filled with } \\
\text { microvoids, surrounded by PCU }\end{array}$ \\
\hline Physio-L (K2M) NA & 1-piece viscoelastic, no articulating surface & $\mathrm{Ti}-\mathrm{PCU}$ - Ti multidurometer core \\
\hline
\end{tabular}

$\mathrm{CoCr}=$ cobalt chrome; $\mathrm{PCU}=$ polycarbonate urethane; $\mathrm{SPCU}=$ silicone polycarbonate urethane; $\mathrm{Ti}$ = titanium alloy; $\mathrm{UHMWPE}=$ ultra high molecular weight polyethylene

FDA status: ${ }^{\text {A }}$ Approved; ${ }^{\mathrm{I}}$ Investigational; ${ }^{\mathrm{NA}}$ Not approved, not involved in IDE trial at this time

One-piece discs consist of combinations of metal and polymers or graduated modulus elastomers, where simultaneous injection of polymers with different moduli (stiffness) provides a dual modulus disc with a graduated modulus region. Designs with one or more components implanted as one piece can potentially provide performance characteristics most like those of a healthy disc because they are viscoelastic. ${ }^{77}$ They can simulate a disc to a large extent, but with equal and reduced ${ }^{19,77}$ ROM in every direction due to the homogeneous material. The natural intervertebral disc needs dampening properties for producing motion, because it does not have typical joint surfaces.

To date, there is no research addressing whether a particular TDR design may be better for some patients than for others. Kinematic studies may be needed to determine if motion pattern or other characteristics afforded by a particular design may best address specific needs of an individual patient. 


\section{Specific Indications for Lumbar TDR}

There is no guide to "determine the right patient with the right indication for the right TDR." More is known about the "right patient" than the "right total disc," nearly nothing about the "right TDR type." Bertagnoli et al. ${ }^{78}$ correlated surgical outcome with indications and categorized prime, good, borderline, and poor indications based on combinations of the number of levels operated, disc space height, and the condition of facet joints and adjacent segments. The authors always used the same disc in these different patient groups, as no viscoelastic disc was marketed at the time.

Compared to discs with spherical ball and socket gliding surfaces (Table 2), viscoelastic discs may be judged on their design expanding TDR indications. But there are differences between various viscoelastic discs and between different ball and socket discs. Thus it is impossible to propose specific indications for all ball and socket discs and for all viscoelastic discs.

It is desired to determine the "right TDR" for each patient, but no clinical TDR guide exists. In comparison to spherical ball and socket discs (Table 3 ) advantages of viscoelastic discs are related to more stable biomechanical properties.

Table 3. Functional Properties of Ball and Socket vs. Viscoelastic TDRs.

\begin{tabular}{|l|l|l|l|}
\hline Characteristic Compared to Natural Disc & Metal-on-Metal & Metal-on-Poly & Viscoelastic one-Piece \\
\hline 1. Restoration of normal/adjacent Disc Height & $(+)$ & $(+)$ & $(+)$ \\
\hline 2. Restoration of Disc Angle & $(+)$ & $(+)$ & $(+)$ \\
\hline 3. Mimics Quantity of Motion (ROM) & - & - & $(-)$ \\
\hline 4. Mimics Quality of Motion (stiffness, COR, NZ) & - & - & $(-)$ \\
\hline 5. Stability (Passive Restraint) & - & - & $(+)$ \\
\hline 6. Shock Damping & - & $(-)$ & + \\
\hline
\end{tabular}

1. \& 2. Restoration of normal disc height and disc angle depends on the assortment of available implants in relation to patient's disc height and disc angle variations. The disc height is most stable in the long run in metal-on-metal discs, followed by metal-on-poly implants. Most viscoelastic one-piece discs can better sustain the disc angle than functional 2- or 3-component discs.

3. No disc has physiological ROM to the different directions (sagittal, frontal, transversal plane). Spherical ball and socket discs imply always hypermobility.

4. There is no disc with complete qualitative physiological features.

5. Stability is not to separate from quantity and quality of motion. The intervertebral motion has much more resistance in viscoelastic discs.

6. Damping function is the pre-condition for any motion in viscoelastic one-piece discs. Material Poly has a low degree of elasticity.

Devices providing suitable ROM and stability may be appropriate for patients with a wide set of TDR indications. Huang et al. ${ }^{65}$ suggested contraindications may vary between different implant designs, specifically related to constraint, noting that constrained designs may be more suitable for patients with instability such as spondylolisthesis or post-facetectomy instability, or patients with mild facet arthrosis. Some 1-piece viscoelastic discs have limited ROM which may not protect adjacent levels. 
Many questions must be answered before having specific indications for the "right total disc," including:

1. Is there osteoporosis/osteopenia?

2. Is there structural or degenerative scoliosis?

3. Is there a loss of lordotic angle in the segment or the lumbar spine as a whole?

4. Is there central stenosis?

5. Is there foraminal stenosis?

6. Is there a pars defect?

7. Is there anterolisthesis?

8. Is there retrolisthesis?

9. Is there lateral olisthesis?

10. How unstable is the segment?

11. How much height has the disc lost compared to a healthy adjacent disc?

12. Are Modic changes present?

13. Are facet joints normal?

14. Are there osteophytes and where?

15. At what point is the disc in the degenerative cascade?

16. Is there calcification of abdominal vessels?

17. How do observations equate with symptoms and signs?

18. Are there further absolute or relative contraindications?

\section{Indication Guide for Lumbar TDR}

The literature review was assimilated into an overview on TDR patient selection. The target of this study was to improve the surgeon's decision making for the "right patient" with the "right indication," and the "right TDR." The proposals in Table 4 are not yet the final version, but a step toward being more precise in selection for TDR. Functional threeand two-component ball and socket discs have gliding areas not providing physiological ROM in all directions. In the future those TDRs will probably be replaced by implants with real physiological ROM, which 1-piece devices do not have. Table 4 is not intended to be comprehensive, but rather to identify what else should be evaluated when decision making is not clear. 
Table 4. Proposed overview how to determine types of TDR in relation to patient selection criteria.

\begin{tabular}{|c|c|c|c|c|c|}
\hline & Preoperative factor & $\begin{array}{l}\text { Functional three } \\
\text { component spherical } \\
\text { ball and socket disc }\end{array}$ & $\begin{array}{l}\text { Functional two } \\
\text { component } \\
\text { spherical ball and } \\
\text { socket disc }\end{array}$ & $\begin{array}{l}\text { One-piece } \\
\text { viscoelastic disc with } \\
\text { movable core }\end{array}$ & $\begin{array}{l}\text { Compact (stiff) } \\
\text { one-piece } \\
\text { viscoelastic } \\
\text { disc }\end{array}$ \\
\hline \multicolumn{6}{|c|}{ Patient Selection Criteria } \\
\hline \multirow[t]{5}{*}{$\begin{array}{l}\text { Patient data } \\
\text { and medical } \\
\text { history }\end{array}$} & Age & $20-40$ & $20-40$ & $30-50$ & $\begin{array}{l}40->60 \\
\text { (precondition } \\
>50 \mathrm{y}: \text { sclerosis } \\
\text { of endplates) }\end{array}$ \\
\hline & Back pain & yes & yes & yes & yes \\
\hline & Leg pain & yes & yes & yes & yes, no $>50 y$ \\
\hline & $\begin{array}{l}\text { Duration of non-surgical } \\
\text { treatment }\end{array}$ & $\begin{array}{l}20-30 \text { y: } 9 \text { months } \\
30-40 \text { y: } 6 \text { months }\end{array}$ & $\begin{array}{l}20-30 \text { y: } 9 \text { months } \\
30-40 \text { y: } 6 \text { months }\end{array}$ & $\begin{array}{l}30-40 \text { y: } 6 \text { months } \\
40-50 \text { y: } 5 \text { months }\end{array}$ & $\begin{array}{l}40-50 \text { yrs: } 5 \\
\text { months } 50-60 \\
\text { yrs: } 4 \text { months } \\
>60: 3 \text { months }\end{array}$ \\
\hline & Prior surgery & $\begin{array}{l}\text { no (besides } \\
\text { nucleotomy/ } \\
\text { discectomy without } \\
\text { destabilizing bone } \\
\text { resection) }\end{array}$ & $\begin{array}{l}\text { no (besides } \\
\text { nucleotomy/ } \\
\text { discecomy without } \\
\text { destabilizing bone } \\
\text { resection) }\end{array}$ & $\begin{array}{l}\text { no (besides } \\
\text { nucleotomy/ } \\
\text { discectomy without } \\
\text { destabilizing bone } \\
\text { resection) }\end{array}$ & $\begin{array}{l}\text { yes (without } \\
\text { facet-resection } \\
\text { or } \\
\text { laminectomy) }\end{array}$ \\
\hline \multirow{2}{*}{$\begin{array}{l}\text { Pain and } \\
\text { disability }\end{array}$} & VAS & $>50 / 100$ & $>50 / 100$ & $>40 / 100$ & $>40 / 100$ \\
\hline & ODI & $\geq 40 / 100$ & $\geq 40 / 100$ & $\geq 40 / 100$ & $\geq 40 / 100$ \\
\hline $\begin{array}{l}\text { Clinical } \\
\text { findings }\end{array}$ & $\begin{array}{l}\text { No severe nerve stretching } \\
\text { findings }\end{array}$ & $\begin{array}{l}\text { no severe nerve } \\
\text { stretching findings }\end{array}$ & $\begin{array}{l}\text { no severe nerve } \\
\text { stretching findings }\end{array}$ & $\begin{array}{l}\text { no severe nerve } \\
\text { stretching findings }\end{array}$ & $\begin{array}{l}\text { No severe nerve } \\
\text { stretching } \\
\text { findings }\end{array}$ \\
\hline \multirow[t]{8}{*}{$\begin{array}{l}\text { Radiographic } \\
\text { findings }\end{array}$} & $\begin{array}{l}\text { Maximal reduced disc height } \\
\text { compared to upper healthy } \\
\text { disc }\end{array}$ & $1 / 2$ & $1 / 2$ & $1 / 2$ & $2 / 3$ \\
\hline & Osteochondrosis & yes & yes & yes & yes \\
\hline & $\begin{array}{l}\text { Degenerative } \\
\text { spondylolisthesis }\end{array}$ & no & no & no & $\mathrm{Yes}<3 \mathrm{~mm}$ \\
\hline & Isthmic spondylolisthesis & no & no & no & no \\
\hline & Degenerative scoliosis & no & no & minimal & yes \\
\hline & Bony stenosis of spinal canal & no & no & no & no \\
\hline & Facet arthritis grades ${ }^{85}$ & up to grade II & up to grade II & up to grade II & up to grade III \\
\hline & Facetectomy & no & no & no & no \\
\hline \multirow[t]{2}{*}{ MRI } & $\begin{array}{l}\text { Nucleus pulposus prolapse at } \\
\text { disc level with nerve root } \\
\text { irritation (= anterior } \\
\text { discectomy possible) }\end{array}$ & yes & yes & yes & yes \\
\hline & Modic changes & yes & yes & yes & yes \\
\hline \multirow{3}{*}{$\begin{array}{l}\text { Invasive } \\
\text { diagnostic } \\
\text { procedures }\end{array}$} & Facet joint injection & no reduced pain & no reduced pain & no reduced pain & $\begin{array}{l}<50 \% \text { reduced } \\
\text { pain }\end{array}$ \\
\hline & Specific pain at discography & yes & yes & yes & yes \\
\hline & $\begin{array}{l}\text { Reduced leg pain at } \\
\text { periradicular injection }\end{array}$ & $+/-$ & $+/-$ & $+/-$ & $+/-$ \\
\hline
\end{tabular}




\begin{tabular}{|l|l|l|l|l|l|}
\hline Bone quality & DEXA & T>-1.0 & $\mathrm{T}>-1.0$ & $\mathrm{~T}>-1.0$ & $\mathrm{~T}>-1.0$ \\
\hline $\begin{array}{l}\text { Psychosocial } \\
\text { psychological } \\
\text { factors }\end{array}$ & Result of test(s) & negative & negative & negative & negative \\
\hline $\begin{array}{l}\text { Surgical } \\
\text { experience }\end{array}$ & Possible number of levels & 1 & $1-2$ & $1-2$ & $>2$ \\
\hline
\end{tabular}

\section{Final remarks}

The ideal TDR candidate may be an individual between 35 and 45 years old, with back pain severe enough to impact activities of daily living and/or work. Symptomatic DDD with or without radicular pain is the primary indication for TDR. Indications for TDR are based on patients' clinical problems, on several image findings, and other information. Three examples:

- Low back pain (DDD) caused by osteochondrosis

- Sciatica associated with degenerative spondylolisthesis $<3 \mathrm{~mm}$

- Sciatica after nucleotomy

In summary, we believe TDR candidates should have failed sufficient nonoperative treatment, have no structural anatomic abnormalities, have BMD T score $>-1.0$, no significant psychological issues, and diagnostic studies confirming the disc as the pain generator. All major contraindications should be absent. There are few viscoelastic discs, but they may offer advantages over current ball and socket devices; more outcome data is needed to determine if they expand TDR indications. Three- and two-component discs with physiological ROM are not yet developed.

\section{References}

1. Singh K, Vaccaro AR, Albert TJ. Assessing the potential impact of total disc arthroplasty on surgeon practice patterns in North America. Spine J 2004;4:195S-201S.

2. Lemaire JP, Skalli W, Lavaste F, et al. Intervertebral disc prosthesis. Results and prospects for the year 2000. Clin Orthop Relat Res 1997:64-76.

3. Hanley EN, Jr. The indications for lumbar spinal fusion with and without instrumentation. Spine 1995;20:143S-53S.

4. Bambakidis NC, Feiz-Erfan I, Klopfenstein JD, et al. Indications for surgical fusion of the cervical and lumbar motion segment. Spine 2005;30:S2-6.

5. Guyer RD, McAfee PC, Banco RJ, et al. Prospective, randomized, multicenter Food and Drug Administration Investigational Device Exemption study of lumbar total disc replacement with the Charite artificial disc versus lumbar fusion: Five-year follow-up. Spine J 2009;9:374-86.

6. Zigler JE, Delamarter RB. Five-year results of the prospective, randomized, multicenter, Food and Drug Administration investigational device exemption study of the ProDisc-L total disc replacement versus circumferential arthrodesis for the treatment of single-level degenerative disc disease. J Neurosurg Spine 2012;17:493-501. 
7. Wong DA, Annesser B, Birney T, et al. Incidence of contraindications to total disc arthroplasty: A retrospective review of 100 consecutive fusion patients with a specific analysis of facet arthrosis. Spine J 2007;7:5-11.

8. Anderson PA, Rouleau JP. Intervertebral disc arthroplasty. Spine 2004;29:2779-86.

9. Blumenthal S, McAfee PC, Guyer RD, et al. A prospective, randomized, multicenter Food and Drug Administration Investigational Device Exemptions study of lumbar total disc replacement with the Charite artificial disc versus lumbar fusion: Part I: Evaluation of clinical outcomes. Spine 2005;30:1565-75.

10. BBraun. Activ L lumbar disc prosthesis. http://www.bbraun.com/cps/rde/xchg/ bbraun-com $/$ hs.xsl/products.html?prid $=\ldots$.

11. Cinotti G, David T, Postacchini F. Results of disc prosthesis after a minimum followup period of 2 years. Spine 1996;21:995-1000.

12. Enker P, Steffee A, McMillin C, et al. Artificial disc replacement. Preliminary report with a 3-year minimum follow-up. Spine 1993;18:1061-70.

13. Fraser RD, Ross ER, Lowery GL, et al. Acroflex design and results. Spine J 2004;4:245S-51S.

14. Leahy M, Zigler JE, Ohnmeiss DD, et al. Comparison of results of total disc replacement in postdiscectomy patients versus patients with no previous lumbar surgery. Spine 2008;33:1690-3.

15. Lemaire JP, Carrier H, Sariali el H, et al. Clinical and radiological outcomes with the Charite artificial disc: A 10-year minimum follow-up. J Spinal Disord Tech 2005;18:353-9.

16. McAfee PC. The indications for lumbar and cervical disc replacement. Spine $\mathrm{J}$ 2004;4:177S-81S.

17. Putzier M, Funk JF, Schneider SV, et al. Charite total disc replacement--clinical and radiographical results after an average follow-up of 17 years. Eur Spine J 2006;15:183-95.

18. Regan JJ, McAfee PC, Blumenthal SL, et al. Evaluation of surgical volume and the early experience with lumbar total disc replacement as part of the investigational device exemption study of the Charite artificial disc. Spine 2006;31:2270-6.

19. Rischke B, Ross RS, Jollenbeck BA, et al. Preclinical and clinical experience with a viscoelastic total disc replacement. SAS J 2011;5:97-107.

20. Rohlmann A, Zander T, Bergmann G. Effect of total disc replacement with ProDisc on intersegmental rotation of the lumbar spine. Spine 2005;30:738-43.

21. Sasso RC, Foulk DM, Hahn M. Prospective, randomized trial of metal-on-metal artificial lumbar disc replacement: Initial results for treatment of discogenic pain. Spine 2008;33:123-31.

22. Siepe CJ, Hitzl W, Meschede P, et al. Interdependence between disc space height, range of motion and clinical outcome in total lumbar disc replacement. Spine 2009;34:904-16.

23. Siepe CJ, Mayer HM, Heinz-Leisenheimer M, et al. Total lumbar disc replacement: Different results for different levels. Spine 2007;32:782-90.

24. Siepe CJ, Mayer HM, Wiechert K, et al. Clinical results of total lumbar disc replacement with ProDisc II: Three-year results for different indications. Spine 2006;31:1923-32.

25. Tropiano P, Huang RC, Girardi FP, et al. Lumbar total disc replacement. Seven to eleven-year follow-up. J Bone Joint Surg Am 2005;87:490-6. 
26. Tropiano P, Huang RC, Girardi FP, et al. Lumbar disc replacement: Preliminary results with ProDisc II after a minimum follow-up period of 1 year. J Spinal Disord Tech 2003;16:362-8.

27. van den Eerenbeemt KD, Ostelo RW, van Royen BJ, et al. Total disc replacement surgery for symptomatic degenerative lumbar disc disease: A systematic review of the literature. Eur Spine J 2010;19:1262-80.

28. Zweig T, Aghayev E, Melloh M, et al. Influence of preoperative leg pain and radiculopathy on outcomes in mono-segmental lumbar total disc replacement: Results from a nationwide registry. Eur Spine J 2012;21(Suppl 6):S729-S736.

29. Zigler J, Delamarter R, Spivak JM, et al. Results of the prospective, randomized, multicenter Food and Drug Administration Investigational Device Exemption study of the ProDisc-L total disc replacement versus circumferential fusion for the treatment of 1-level degenerative disc disease. Spine 2007;32:1155-62.

30. Bertagnoli R, Yue JJ, Shah RV, et al. The treatment of disabling single-level lumbar discogenic low back pain with total disc arthroplasty utilizing the ProDisc prosthesis: A prospective study with 2-year minimum follow-up. Spine 2005;30:2230-6.

31. Chin KR. Epidemiology of indications and contraindications to total disc replacement in an academic practice. Spine J 2007;7:392-8.

32. Delamarter RB, Fribourg DM, Kanim LE, et al. ProDisc artificial total lumbar disc replacement: Introduction and early results from the United States clinical trial. Spine 2003;28:S167-75.

33. Geisler FH, Blumenthal SL, Guyer RD, et al. Neurological complications of lumbar artificial disc replacement and comparison of clinical results with those related to lumbar arthrodesis in the literature: Results of a multicenter, prospective, randomized investigational device exemption study of Charite intervertebral disc. Invited submission from the Joint Section Meeting on Disorders of the Spine and Peripheral Nerves, March 2004. J Neurosurg Spine 2004;1:143-54.

34. German JW, Foley KT. Disc arthroplasty in the management of the painful lumbar motion segment. Spine 2005;30:S60-7.

35. Hochschuler SH, Ohnmeiss DD, Guyer RD, et al. Artificial disc: Preliminary results of a prospective study in the United States. Eur Spine J 2002;11 Suppl 2:S106-10.

36. Gornet MF, Burkus JK, Dryer RF, et al. Lumbar disc arthroplasty with Maverick disc versus stand-alone interbody fusion: A prospective, randomized, controlled, multicenter Investigational Device Exemption trial. Spine 2011;36:E1600-E11.

37. Pimenta L, Springmuller R, Lee CK, et al. Clinical performance of an elastomeric lumbar disc replacement: Minimum 12 months follow-up. SAS J 2010;4:16-25.

38. Berg S, Tullberg $\mathrm{T}$, Branth $\mathrm{B}$, et al. Total disc replacement compared to lumbar fusion: A randomised controlled trial with 2-year follow-up. Eur Spine J 2009;18:1512-9.

39. Bertagnoli R, Yue JJ, Nanieva R, et al. Lumbar total disc arthroplasty in patients older than 60 years of age: A prospective study of the ProDisc prosthesis with 2-year minimum follow-up period. J Neurosurg Spine 2006;4:85-90.

40. David T. Long-term results of one-level lumbar arthroplasty: Minimum 10-year follow-up of the Charite artificial disc in 106 patients. Spine 2007;32:661-6.

41. Mayer HM, Wiechert K, Korge A, et al. Minimally invasive total disc replacement: Surgical technique and preliminary clinical results. Eur Spine J 2002;11 Suppl 2:S124-30. 
42. Steib JP, Beaurain J, Delecrin J. The mobidisc prosthesis. http://www.mediform.cz/ Data/files/odborne_studie/ldr/MOBIDISC\%20prosthes....

43. Zeegers WS, Bohnen LM, Laaper M, et al. Artificial disc replacement with the modular type sb Charite III: 2-year results in 50 prospectively studied patients. Eur Spine J 1999;8:210-7.

44. Bertagnoli R, Yue JJ, Shah RV, et al. The treatment of disabling multilevel lumbar discogenic low back pain with total disc arthroplasty utilizing the ProDisc prosthesis: A prospective study with 2-year minimum follow-up. Spine 2005;30:2192-9.

45. Hedman TP, Kostuik JP, Fernie GR, et al. Design of an intervertebral disc prosthesis. Spine 1991;16:S256-60.

46. Jehan S, Elsayed S, Webb J, et al. L5-S1 disc replacement after two previous fusion surgeries for scoliosis. Eur Spine J 2011;20:669-73.

47. Geisler FH, Guyer RD, Blumenthal SL, et al. Patient selection for lumbar arthroplasty and arthrodesis: The effect of revision surgery in a controlled, multicenter, randomized study. J Neurosurg Spine 2008;8:13-6.

48. Blondel B, Tropiano P, Gaudart J, et al. Clinical results of total lumbar disc replacement regarding to various aetiologies of the disc degeneration: A study with a 2 years minimal follow-up. Spine 2011;36:E313-E9.

49. Regan JJ. Clinical results of Charite lumbar total disc replacement. Orthop Clin North Am 2005;36:323-40.

50. Hasz MW. Diagnostic testing for degenerative disc disease. Adv Orthop 2012;2012:413913.

51. Le Huec J, Basso Y, Mathews H, et al. The effect of single-level, total disc arthroplasty on sagittal balance parameters: A prospective study. Eur Spine J 2005; 14:480-6.

52. Tournier C, Aunoble S, Le Huec JC, et al. Total disc arthroplasty: Consequences for sagittal balance and lumbar spine movement. Eur Spine J 2007;16:411-21.

53. Chung SS, Lee CS, Kang CS, et al. The effect of lumbar total disc replacement on the spinopelvic alignment and range of motion of the lumbar spine. J Spinal Disord Tech 2006;19:307-11.

54. Kasliwal MK, Deutsch H. Effect of total lumbar disc replacement on lumbosacral lordosis. J Spinal Disord Tech 2012;25:370-3.

55. Chou R, Atlas SJ, Stanos SP, et al. Nonsurgical interventional therapies for low back pain: A review of the evidence for an American Pain Society clinical practice guideline. Spine 2009;34:1078-93.

56. Walker J, 3rd, El Abd O, Isaac Z, et al. Discography in practice: A clinical and historical review. Curr Rev Musculoskelet Med 2008;1:69-83.

57. Thalgott JS, Albert TJ, Vaccaro AR, et al. A new classification system for degenerative disc disease of the lumbar spine based on magnetic resonance imaging, provocative discography, plain radiographs and anatomic considerations. Spine J 2004;4:167S-72S.

58. Berg S, Isberg B, Josephson A, et al. The impact of discography on the surgical decision in patients with chronic low back pain. Spine J 2012;12:283-91.

59. Lee CK. Osteopenia and total disc prosthesis subsidence: Inclusion/exclusion criteria for total disc replacement. SAS J 2007;1:82-.

60. World Health Organization. Prevention and management of osteoporosised. Geneva, Switzerland: World Health Organization, 2003. 
61. Linton S. A review of psychological risk factors in back and neck pain. Spine 2000;25:1148-56.

62. Halpin RJ, Sugrue PA, Gould RW, et al. Standardizing care for high-risk patients in spine surgery: The northwestern high-risk spine protocol. Spine 2010;35:2232-8.

63. Daubs MD, Norvell DC, McGuire R, et al. Fusion versus nonoperative care for chronic low back pain: Do psychological factors affect outcomes? Spine 2011;36:S96-109.

64. Zigler J, Ohnmeiss DD. Comparison of 2-level versus 1-level total disc replacement: Results from a prospective FDA-regulated trial. SAS J 2008;2:140-4.

65. Huang RC, Lim MR, Girardi FP, et al. The prevalence of contraindications to total disc replacement in a cohort of lumbar surgical patients. Spine 2004;29:2538-41.

66. Zeh A, Planert M, Siegert G, et al. Release of cobalt and chromium ions into the serum following implantation of the metal-on-metal Maverick-type artificial lumbar disc (Medtronic Sofamor Danek). Spine 2007;32:348-52

67. Gornet MF, Burkus JK, Harper ML, et al: Prospective study on serum metal levels in patients with metal-on-metal lumbar disc arthroplasty. Eur Spine J 2013;22:741-746.

68. Guyer RD, Pettine K, Dimmig TC, D., et al: Five-year follow-up of a prospective, randomized FDA IDE trial comparing two lumbar total disc replacements: Clinical outcome and serum ion level analysis for a metal-on-metal device. Presented at the International Society for the Study of the Lumbar Spine. Scottsdale, Arizona; May, 2013.

69. Medicines and Healthcare products Regulatory Agency: Medical Device Alert: All metal-on-metal (MoM) hip replacements. MDA/2010/033; April 22, 2010.

70. Van Der Straeten C, Grammatopoulos G, Gill HS, et al: The 2012 Otto Aufranc Award: The interpretation of metal ion levels in unilateral and bilateral hip resurfacing. Clin Orthop Relat Res 2013;471:377-385.

71. Imanishi T, Hasegawa M, Sudo A. Serum metal ion levels after second-generation metal-on-metal total hip arthroplasty. Arch Orthop Trauma Surg 2010;130:1447-50.

72. Lardanchet JF, Taviaux J, Arnalsteen D, et al. One-year prospective comparative study of three large-diameter metal-on-metal total hip prostheses: Serum metal ion levels and clinical outcomes. Orthop Traumatol Surg Res 2012;98:265-74.

73. Nikolaou VS, Petit A, Debiparshad K, et al. Metal-on-metal total hip arthroplasty five- to 11-year follow-up. Bull NYU Hosp Jt Dis 2011;69 Suppl 1:S77-83.

74. O'Leary P, Nicolakis M, Lorenz MA, et al. Response of Charite total disc replacement under physiologic loads: Prosthesis component motion patterns. Spine J 2005;5:590-9.

75. Kafer W, Clessienne CB, Daxle M, et al. Posterior component impingement after lumbar total disc replacement: A radiographic analysis of 66 ProDisc-L prostheses in 56 patients. Spine 2008;33:2444-9.

76. Lebl DR, Cammisa FP, Girardi FP, et al. In vivo functional performance of failed ProDisc-L devices: Retrieval analysis of lumbar total disc replacements. Spine 2012;37:E1209-17.

77. Ross ERS. Stiffness: A key mechanical factor in normal, degenerate and artificial lumbar intervertebral discs. Doctoral Thesis 2011.

78. Bertagnoli R, Kumar S. Indications for full prosthetic disc arthroplasty: A correlation of clinical outcome against a variety of indications. Eur Spine J 2002;11 Suppl 2:S131-6. 
79. Delamarter RB, Bae HW, Pradhan BB. Clinical results of ProDisc-II lumbar total disc replacement: Report from the United States clinical trial. Orthop Clin North Am 2005;36:301-13.

80. Guyer RD, McAfee PC, Hochschuler SH, et al. Prospective randomized study of the Charite artificial disc: Data from two investigational centers. Spine J 2004;4:252S-9S.

81. Siepe CJ, Tepass A, Hitzl W, et al. Dynamics of improvement following total lumbar disc replacement: Is the outcome predictable? Spine 2009;34:2579-86.

82. Zweig T, Aghayev E, Melloh M, et al. Influence of preoperative leg pain and radiculopathy on outcomes in mono-segmental lumbar total disc replacement: Results from a nationwide registry. Eur Spine J 2012;21:S729-S36.

83. Leary SP, Regan JJ, Lanman TH, et al. Revision and explantation strategies involving the Charite lumbar artificial disc replacement. Spine 2007;32:1001-11.

84. de Kleuver M, Oner FC, Jacobs WC. Total disc replacement for chronic low back pain: Background and a systematic review of the literature. Eur Spine J 2003;12:108-16.

85. Fujiwara A, Lim TH, An HS, et al. The effect of disc degeneration and facet joint osteoarthritis on the segmental flexibility of the lumbar spine. Spine 2000;25:3036-44.

\section{Corresponding Author}

Karin Büttner-Janz, Dr.med., Prof. Büttner-Janz Spinefoundation, Meinekestr. 6, 10719 Berlin, Germany.buettner-janz@spinefoundation.info

\section{Disclosures}

Rick Guyer, MD is a consultant for DePuy Spine and K2M.

Copyright (C) 2015 ISASS - International Society for the Advancement of Spine Surgery. To see more or order reprints or permissions, see http://ijssurgery.com. 